DOI: https://doi.org/10.15407/techned2018.06 $: \underline{034}$

\title{
ANALYSIS OF THE STABILITY OF A PULSE POWER SUPPLY FOR MICRO RESISTANCE WELDING
}

Journal

Publisher

ISSN

Issue

Pages
Tekhnichna elektrodynamika

Institute of Electrodynamics National Academy of Science of Ukraine 1607-7970 (print), 2218-1903 (online)

No 6, 2018 (November/December)

$34-37$

\section{Authors}

V.O. Didenko*, O.F. Bondarenko**, Yu.V. Bondarenko***, Ye.V. Verbytskyi ${ }^{\star * \star *}$

National Technical University of Ukraine «lgor Sikorsky Kyiv Polytechnic Institute», pr. Peremohy, 37, Kyiv, 03056, Ukraine, e-mail: bondarenkoaf@gmail.com

* ORCID ID : http://orcid.org/0000-0003-2091-2069

** ORCID ID : http://orcid.org/0000-0002-4276-1145

*** ORCID ID : http://orcid.org/0000-0002-1803-0684

**** ORCID ID : http://orcid.org/0000-0001-7275-5152

\section{Abstract}

In this paper, a pulse power supply for micro resistance welding machine, operating in the Interleaved mode is considered. Sharp changes of the welding contact resistance during the welding process are identified as the main factor influencing the stability of the power supply. In order to determine the conditions for achieving the stable operation of the power supply, the analysis of its stability as of a closed automatic control system was carried out. That made it 
possible to adjust the current regulator in accordance with the requirement of ensuring high reproducibility of the necessary laws for welding current when the welding contact resistance changes during the welding. The influence of the contact resistance on the area of stability is graphically shown. References 10, figures 4 .

Key words: micro resistance welding, pulse-width converter, modular structure, automatic control, stability.

Received: 05.03 .2018

Accepted: 04.05 .2018

Published: 23.10 .2018

\section{References}

1. Ataush V.E., Leonov V.P., Moskvin E.G. Micro Resistance Welding in Instrument Making. Riga: RTU, 1996. (Rus)

2. Bondarenko A.F. Current pulses generators for micro resistance welding machines. $\mathrm{PhD}$ thesis. Alchevsk, 2007. 211 p. (Rus)

3. Bondarenko O.F., Khyzhniak T.A., Kuzin D.V. Energy Losses in Multicell-Type Transistor Converter for Resistance Welding. Tekhnichna Elektrodynamika. 2015. No 5. Pp. 21-25. (Ukr) 4. Bondarenko lu.V. Multicell-type Transistor Converter with Combined Continuous and Pulse Control for Micro Resistance Wel-ding. PhD thesis. Alchevsk, 2012. 148 p. (Ukr)

5. Lanin V.L., Rubtsevich I.I., Kerentsev A.F. Increase of reliability of micro-contact joints of radiation stable power transistors. Silovaia Elektronika. 2010. No 3. Pp. 100-105. (Rus)

6. Lukas V.A. Theory of automatic control. Moskva: Nedra, 1990. 416 p. (Rus)

7. Brooks S.W., Maggloino L.J. Method and apparatus for an efficient multiphase switching regulator. Patent US 6285571, 2001.

8. Gnyusov S.F., Kiselev A.S., Slobodyan M.S., Sovetchenko B.F., Nekhoda M.M., Srukov 
A.V., Yurin P.M. Formation of a joint in resistance spot microwelding. Welding International. 2005. Vol. 19. No 9. Pp. 737-741. DOI:

http://dx.doi.org/10.1533/wint.2005.3510

9. Slobodyan M.S. Methods of Creation of Permanent Zirconium Alloy Joints in Reactor Art: A Review. Tsvetnye Metally. 2016. No 10. Pp. 91-98. DOI: http://dx.doi.org/10.17580/tsm.2016. 10.13

10. Zhou Y. Norman. Microjoining and nanojoining. Elsevier, 2008. 832 p. DOI: https://doi.org/ $\underline{10.1533 / 9781845694043}$

PDF 